\title{
Arundo donax L.: An overview on its traditional and ethnomedicinal importance, phytochemistry and pharmacological aspects
}

\author{
Pardeep Kumar $^{\mathbb{D}}$, Sarvjeet Singh ${ }^{\mathbb{D}}$, Aakash Sharma ${ }^{\mathbb{D}}$, Gunjot Kaur ${ }^{\mathbb{D}}$, Ravneet Kaur ${ }^{\mathbb{D}}$, Anand Narain Singh ${ }^{* \mathbb{D}}$ \\ Soil Ecosystem and Restoration Ecology Lab, Department of Botany, Panjab University, Chandigarh-160014, India
}

\section{A R T I C L E I N F O}

Article Type:

Review

\section{Article History:}

Received: 30 September 2020

Accepted: 12 January 2021

\section{Keywords:}

Arundo donax

Ethnomedicinal values

Pharmacology

Phytochemistry

Giant reed

\begin{abstract}
A B S T RAC T
Arundo donax L. (Giant reed) is a grass species belong to Poaceae family with a myriad of uses such as traditional and ethnomedicinal values, bioenergy, and socio-economic importance. The plant is used in conventional medicine to treat various disorders related to skin, gastrointestinal, skeletal, menstrual problems, respiratory and urinary diseases. The present review summarises the scattered information on socio-economic importance, ethnomedicinal uses, phytochemistry and pharmacological aspects of this plant. We conducted a rigorous literature survey using databases such as Scopus, Science Direct, Web of Science, Google Scholar, and PubMed entering keywords like A. donax, Giant reed, and Spanish reed, etc. Phytochemical investigations have identified several alkaloids, terpenoids, sterols, phenolics, and lignin derivatives. The isolated phytoconstituents are reported to exhibit multiple pharmacological activities such as anti-bacterial, anti-oxidant, anti-proliferative, anti-spasmolytic, and also used to treat helminthic infestations in cattle. However, the scientific validity of traditional practices to cure various diseases has not been correctly evaluated yet. Therefore, it is recommended to further investigate the plant for clinical trials to unleash its therapeutic importance towards chemical characterisation for drug discovery and development in the pharmacological field.
\end{abstract}

Implication for health policy/practice/research/medical education:

This review article summarised the scattered information on socio-economic importance, ethnomedicinal uses, phytochemistry and pharmacological aspects of Arundo donax, which are the baseline information for future work and further exploration of the therapeutic potential of this plant.

Please cite this paper as: Kumar P, Singh S, Sharma A, Kaur G, Kaur R, Singh AN. Arundo donax L. An overview on its traditional and ethnomedicinal importance, phytochemistry and pharmacological aspects. J Herbmed Pharmacol. 2021;10(3):269-280. doi: 10.34172/jhp.2021.31.

\section{Introduction}

Arundo donax L. (Giant reed) is a perennial and rhizomatous plant that belongs to the Poaceae family and one of the most widespread species of the genus Arundo. The plant is of general occurrence across the globe. It has been included amongst the worst invasive species of the world because it displaces the native flora and deteriorates the ecological state of lands wherever it grows (1). The plant also possesses several medicinal properties, and therefore, has traditionally been used by several ethnic groups across the world to cure various ailments. According to the World Health Organization (WHO), almost $80 \%$ of the world's population relies on indigenous medicinal plants to cure diseases $(2,3)$. With the immense existing potential and rich knowledge about medicinal plants at the ethnic level, the ethnomedicinal system has reinforced the discovery of several therapeutically important drugs such as Quinine and Artemisinin from the Amazon and China, respectively (4). This traditional system of medicine has provided A. donax L. in Ayurvedic texts i.e., Charak Samhitā, Suśruta Samhitā and Mādhava Chikitsā for the treatment of urinary disorders such as Mütrakrcchra, in medical terminology called as Dysuria (5). A large group of people belonging to different ethnic groups and tribes uses this plant for treating fever, urinary disorders, bone fracture, menstrual disorders, and organ 
dysfunction in cattle (6).

In India, the plant is used in several traditional formulations as a vasopressor, uterine stimulator, hypotensive and antispasmodic agent (7). A decoction of its rhizome acts as an emollient, diuretic, galactagogue (for enhancing lactation) and menstrual stimulator (8).

Local Amchi people (herbalist) in the Kinnaur district of Himachal Pradesh use a decoction of the roots to cure cancer (9). In Chinese folk herbal medicine, the rhizome of Giant reed has been using to treat toothache, swollen gums, vomiting and knee osteoarthritis (10). In Manipur (north-eastern) India, the steam of boiled leaves is used to cure chronic haemorrhoids (11). Ethnic Albanian people in Italy use the internal stem membrane of this plant to arrest bleeding $(12,13)$. The roots are diaphoretic, diuretic, emollient $(14,15)$ and used by local peoples to treat cancer in Pakistan $(16,17)$. Apart from this, the plant also possesses socio-economic importance as different ethnic groups use its strong stem and leaf to make rooftops, thatches, basket, and ropes (6). The stem is also used to make musical instruments and fishing nets $(6,14)$. Phytochemical studies have revealed that the plant contains fatty acids, sterols, and secondary metabolites such as alkaloids (tryptamine, bufotenidine, gramine, and arundamine), terpenes, carotenoids and phenols (8).

Bioactive compounds are shown to have remarkable pharmacological properties such as anti-microbial, anti-oxidant, anti-pyretic (18) and anti-tumorous activities (19). Various types of tryptamines viz. $\mathrm{N}, \quad \mathrm{N}$-dimethyltryptamine, 5-methoxy-N, Ndimethyltryptamine, bufotenine, etc., have been isolated from the rhizome, which possesses mild psychedelic effects (20,21). A lectin isolated from the rhizome of Giant reed is reported to have anti-tumorous properties (19). Despite having immense ethnomedicinal importance, there is a lack of systematic account of the literature on Giant reed. To the best of our knowledge, no review article published till date highlighting its ethnomedicinal values and therapeutic potential. Thus, the present study aimed to summarize the existing knowledge of ethnomedicinal uses, phytochemistry, and pharmacological aspects of A. donax $\mathrm{L}$. This review hopefully will provide baseline information for other researchers who intend to work on this plant.

\section{Methods}

To get comprehensive and systematic information on its traditional and ethnomedicinal uses, as well as phytochemistry and pharmacological aspects of this plant, we carried out an extensive survey of literature through available search engines like Scopus, Web of Science, Science Direct, Google Scholar, and PubMed by using keywords such as Arundo donax, Arundo benghalensis, Giant reed, and Spanish reed. We found a total of 95 articles through a search made in the available databases. But we retained 82 articles for the preparation of the present review based on the suitability of the study. Chemical structures of the isolated phytoconstituents were drawn using software ChemDraw Pro 12.0 from Cambridgesoft. All figures were prepared through SigmaPlot 12.0 version software.

\section{Vernacular names}

In India, at the regional and state level, the plant is known by various vernacular names such as Giant reed, River reed, Wild cane, Spanish cane in English; Naal, Baranal, Narasal, Naade in Hindi; Kasa, Dhamana, Potagala, Sunyamadhya in Sanskrit; Noljora, Nol, Gabnol in Assamese; Caravanam, Mudampul, Nanalpul, Velam in Tamil, Yachi in local dialects of Arunachal Pradesh; Nolkhagra in Bengali; Yenthou in Manipuri; Nard, Naal, Narsaal, Naur in local dialects in Jammu; Ama in Malayalam; and Peepalu, Paatuveduru in Telegu. In Ayurveda (The traditional system of medicine in India), the plant is known by various names such as Potgala, Sunayāmadhayā, Dhaman, Devanala. In the Siddha (Tamil) system of medicine, it is known as Korukkai.

\section{Botanical description and ecological distribution}

It is one of the largest members of the genus (Arundo), which attains a luxurious growth with a height of 6-8 m (22). It has a very strong root architecture that penetrates deep into the soil and gives rise to fleshy tuberous rhizomes, which spreads horizontally and forms large thickets. Each stem is hollow, cane-like, divided into distinct nodes and internodes. Leaf-blades are large, somewhat bamboolike, pale to blue-green, distichous, linear to lanceolate, rounded or cordate with a tuft of hairs at base, $30-60 \mathrm{~cm}$ long and $3-5 \mathrm{~cm}$ wide tightly clasped around the stem. The inflorescence is panicle-like $30-60 \mathrm{~cm}$ long with the onset of flowering from June-December (23).

It is thought to be native of South Asia (India, China, Bhutan, Afghanistan, Myanmar, and Thailand) and the Mediterranean region. It moderately grows in several climates across the world and, therefore, has become a naturalised invasive plant species in most of the countries of the European continent, South America, South Africa, Mexico, and the pacific islands (24). Giant reed commonly found along river beds, ditches, and roadsides reproduce through vegetative means by spreading its canes through floodwater and quickly encompass the entire landscape by outcompeting the native vegetation (1). In India, its distribution range generally varies from subtropical low lying Himalayan hills at $600 \mathrm{~m}$ to $2400 \mathrm{~m}$. Morphological attributes and habitats of Giant reed are depicted in Figure 1.

\section{Socio-economic importance}

The Giant reed is a source of livelihood for people of the Meitei community in Manipur, North-East India. 


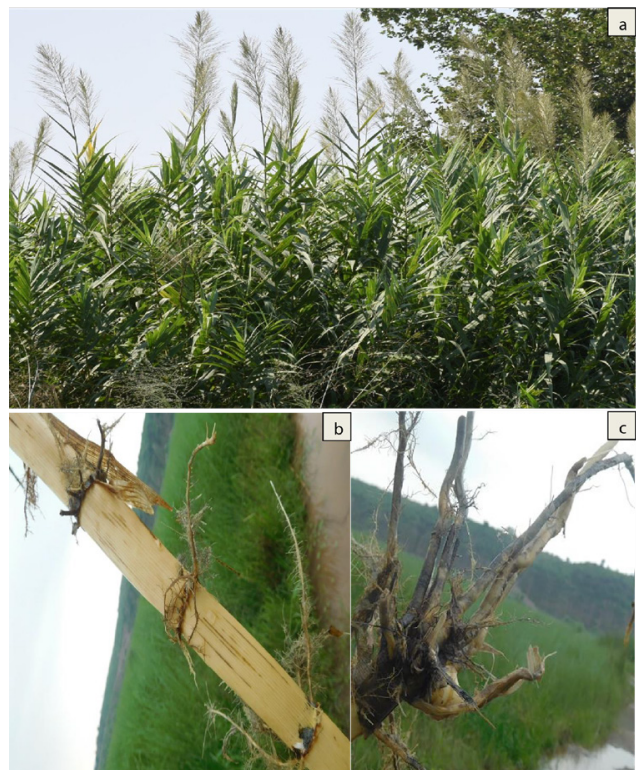

Figure 1. Morphological attributes of Arundo donax L. a) General appearance of the plant with leaves and inflorescence, b) Stem bearing roots at the node, c) Rhizome and cluster of roots.

The plant is commonly used in daily household stuff, life-fencing, soil binder, firewood, and cage for livestock rearing. Thrashing mat made from the stem of this plant costs around 2200-3000 ₹ per piece in the market of Manipur, India (6). Generally, the stem and leaves of the A. donax L. are used to make baskets, mats, ropes, and thatching of huts in Garhwal Himalaya (25). Terminal panicles of $A$. donax L. are also used to make brooms in other parts of India like Uttar Pradesh and Garhwal Himalaya (14,25). Local people from the Mishing tribe in Brahmaputra valley of Assam use the whole plant to keep their rice stock (26). Fumigants after burning of dried leaves of $A$. donax L. are used as mosquito repellents by tribals of Senapati district, Manipur (27).

The stem of the plant is used as a building material, fencing, and supporter for climbing crops and an important source of firewood for local people in Yangzhou, East China, and Manipur, India (6,28). The Tharu tribe of Katarniaghat Wildlife Sanctuary, Uttar Pradesh uses its stem to make fishing rods and walking sticks (14). It is also used in rituals, ceremonies for prayer to forefathers and deities (Apokpa Khurumba) by Chothe tribes in Manipur (29). The stem of Giant reed has been used for making musical instruments or woodwind such as flutes since ancient times $(6,30)$. Besides, it is also used in the paper and pulp industry, source of fuel and phytoremediation of heavy metals (23). Various experimental studies have shown that the roots of this plant accumulate significant concentration of trace elements in sediments and water, and can be used as a promising tool for biomonitoring campaigns of wetlands (31).

\section{Traditional and ethnomedicinal uses}

Different parts of the plant, such as leaves, stem, roots, and rhizome are used in traditional and ethnic formulations to cure a broad spectrum of diseases (Table 1). The plant is well explored in folk medicines as a diuretic, emollient, and to treat skin disorders. An ancient Indian text (in Sushruta) states that if decoction of Arundo donax L.

Table 1. Ethnomedicinal uses of Arundo donax L.

\begin{tabular}{|c|c|c|c|c|}
\hline Disease category & Disease & Part used & Mode of administration/use & References \\
\hline \multirow[t]{2}{*}{$\begin{array}{l}\text { Circulatory } \\
\text { disorders }\end{array}$} & Haemostatic & Stem (Culm) & $\begin{array}{l}\text { The dividing membrane of nodes or internal membrane of stem } \\
\text { is used as a plaster for wounds to prevent infections and induce } \\
\text { cicatrisation. }\end{array}$ & $(12,13,33,34)$ \\
\hline & Dropsy & Rhizome or roots & & $(38,39)$ \\
\hline \multirow{8}{*}{$\begin{array}{l}\text { Dermatological } \\
\text { disorders }\end{array}$} & Leprosy & Leaves and shoots & & (40) \\
\hline & Skin problems & Tender Shoot & The pounded new shoots applied to the affected area. & (41) \\
\hline & & Leaves and stem & & $(42)$ \\
\hline & Eczema & Root & External application of root paste, about $20 \mathrm{~g}$ on affected area & (43) \\
\hline & Condyloma & Roots and leaves & & $(17,39)$ \\
\hline & Erysipelas & & & $(36,44)$ \\
\hline & Astringent & Whole plant & & (45) \\
\hline & & Stem (culm) & & (33) \\
\hline \multirow{4}{*}{$\begin{array}{l}\text { Digestive } \\
\text { disorders }\end{array}$} & $\begin{array}{l}\text { Diarrhoea and } \\
\text { dysentery }\end{array}$ & Whole plant & & (45) \\
\hline & & Roots & $\begin{array}{l}\text { Aqueous decoction of fresh root with adequate salt is given to } \\
\text { cattle to cure dysentery by the Mundas }\end{array}$ & (46) \\
\hline & $\begin{array}{l}\text { Intestinal worms and } \\
\text { typhoid }\end{array}$ & Stem & Fresh green shoots after mixing with honey are given to children & (47) \\
\hline & $\begin{array}{l}\text { Chronic } \\
\text { haemorrhoids }\end{array}$ & Leaves & Leaf boiled in water and steam directed to the anal region & (11) \\
\hline
\end{tabular}


Table 1. Continued

\begin{tabular}{|c|c|c|c|c|}
\hline Disease category & Disease & Part used & Mode of administration/use & References \\
\hline \multirow{2}{*}{$\begin{array}{l}\text { Excretory } \\
\text { problems }\end{array}$} & Diaphoresis & Roots & & $(14-15)$ \\
\hline & & Stem (culm) & & $(33-34)$ \\
\hline \multirow{4}{*}{ Urinary disorders } & Diuretic & Rhizome & Decoction & (48) \\
\hline & & Root & & $(14,15,49)$ \\
\hline & & Roots and Leaves & & (17) \\
\hline & & Stem (culm) & & $(33,34)$ \\
\hline \multirow{6}{*}{ Inflammatory } & Fever & Leaves and shoots & & $(18,36,40,50)$ \\
\hline & Headache & Root & & $(15,51)$ \\
\hline & Headache & - & & $(52)$ \\
\hline & Headache & Root and leaves & & (17) \\
\hline & Tonic, ulcer & - & & (44) \\
\hline & Otitis & Leaves & Vapours & $(32,53)$ \\
\hline \multirow[b]{2}{*}{ Respiratory } & Asthma & Stem & Tender shoot extract with honey is given orally & (54) \\
\hline & Pertussis & Root sap & $\begin{array}{l}\text { A little sugared glass of red sap (cut with sunset under the knot } \\
\text { but left attached to the roots) is taken } 3 \text { times a day. }\end{array}$ & (37) \\
\hline \multirow{3}{*}{ Skeletal } & Bone dislocation & Root and stem & Powder with honey, splints & (55) \\
\hline & & Stem & $\begin{array}{l}\text { Mash prepared after crushing the stem is directly applied for } \\
\text { fracture-dislocation treatment }\end{array}$ & $(56)$ \\
\hline & Leg pain & Stem & & (40) \\
\hline \multirow{9}{*}{$\begin{array}{l}\text { Reproductive } \\
\text { disorders }\end{array}$} & $\begin{array}{l}\text { Menstrual disorders } \\
\text { in cattle }\end{array}$ & Rhizome & Decoction of rhizome stimulates menstrual discharge in cattle & $(8,48)$ \\
\hline & $\begin{array}{l}\text { Menolipsis in } \\
\text { humans }\end{array}$ & Root & $\begin{array}{l}\text { Aqueous decoction of fresh root (ca. } 10 \mathrm{~mL} \text { ) with } 7 \text { long pepper } \\
\text { (Piper longum) paste is given to women at early morning in empty } \\
\text { stomach to cure menolipsis. The drug is given for successive } 3 \\
\text { days just after completion of menstrual cycle by the Lodhas. }\end{array}$ & (46) \\
\hline & Menstrual disorders & Rhizome & $\begin{array}{l}\text { Decoction of rhizome is used to stimulate menstrual discharge } \\
\text { (emmenagogue) }\end{array}$ & $(57,58)$ \\
\hline & & Stem (Culm) & Emmenagogue & $(33,34)$ \\
\hline & Abortifacient & Root & $\begin{array}{l}\text { Root decoction along with Jaggery is taken orally as an } \\
\text { abortifacient. }\end{array}$ & (59) \\
\hline & $\begin{array}{l}\text { Antigalactagogue } \\
\text { (diminish the } \\
\text { secretion of milk) }\end{array}$ & Root & & $(14,39)$ \\
\hline & & Rhizome & Rhizome extract is used with black pepper & $(60)$ \\
\hline & & Leaves & & (53) \\
\hline & $\begin{array}{l}\text { Galactagogue } \\
\text { (stimulate milk } \\
\text { secretion) }\end{array}$ & Stem (culm) & & $(33,34)$ \\
\hline \multirow{3}{*}{ Cancer } & & Roots and leaves & & (17) \\
\hline & & Root and stem & Powder with honey & $(55)$ \\
\hline & & $\begin{array}{l}\text { Rhizome or } \\
\text { rootstock }\end{array}$ & Decoction of rhizome in wine with honey & (39) \\
\hline
\end{tabular}

along with Salix alba L. is given, it can cure chronic fever (7). It has been widely used by local people of Sardinia, Italy for vulnerary (healing of wounds), emmenagogue (stimulation of menstrual discharge), galactagogue (promote lactation), haemostatic (arrest of bleeding), diuretic, diaphoretic, anti-inflammatory and anti-septic purposes (32-34).

Furthermore, about 100-250 g of fresh leaves of Arundo donax L. are given orally to cure worm infestation of cattle in the Jhang district, Pakistan (35). In Ayurvedic formulations, Trinpanchmula kwath Giant reed is used to treat fever, rabies, retention of urine, and erysipelas (36). Roots and rhizome are consumed in $56 \%$ of all ethnomedicinal practices, followed by stem (21\%), leaves (17\%), and whole plant $(7 \%)$, as shown in Figure 2. Furthermore, the use of Giant reed to cure reproductive disorders is most cited (18.18\%), followed by dermatological (14.28\%) and inflammatory diseases (12.98\%) (Figure 3). Out of all the documented ethnomedicinal uses, the plant has been extensively used as a diuretic, followed by emmenagogue, haemostatic, diaphoretic, and antipyretic agents. 


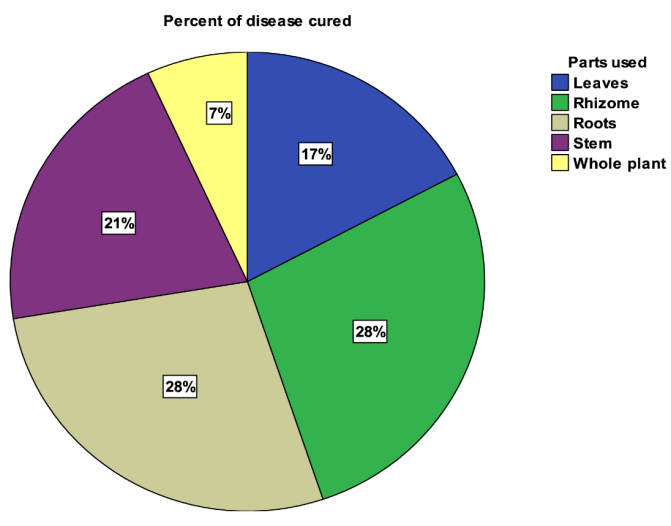

Figure 2. Pictorial representation of percent contribution of different plant parts to cure various diseases.

\section{Phytochemical screening}

The major classes of phytochemicals present in Giant reed are alkaloids, phenols, lignins, sterols, and triterpenoids (Table 2). The Giant reed is source of several classes of phytosterols as shown in Figure 4. The chief alkaloids isolated from the rhizome of Giant reed are bufotenine, dehydrobufotenine, bufotenidine, N, N-dimethyltryptamine, 5-methoxy-N- methyltryptamine, gramine, donaxine, donaxirine, donaxiridine, arundine, and ardine (8). Roots of the Giant reed yields major alkaloids such

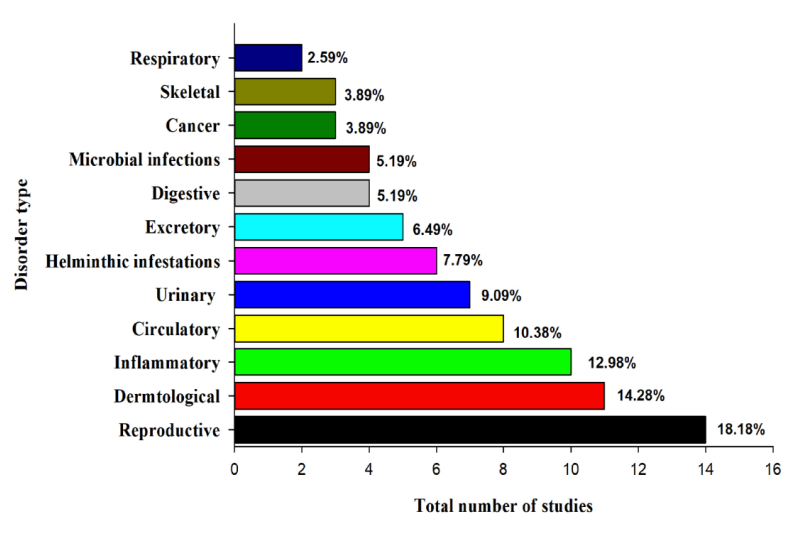

Figure 3. Category wise distribution of different studies as per their biological activities.

as arundaphine (61), arundinine (62), arundamine, arundanine, arundacine, arundarine, and arundavine $(63,64)$ (Table 2). Recently a new bis-indole alkaloid named arundaline and four other known alkaloids i.e., $\mathrm{N}$-acetyltryptamine, trans- $\mathrm{N}$-(p-coumaroyl) serotonin, trans- $\mathrm{N}$-feruloyl serotonin, and tuberosine $\mathrm{B}$ were extracted using 70\% aqueous ethanol extract (10) (Figure 5). The latter four alkaloids were isolated for the first time from Arundo donax L. Besides, the leaves of Giant reed are reported to contain various pharmacologically active

Table 2. The list of reported phytoconstituents from Arundo donax $\mathrm{L}$

\begin{tabular}{|c|c|c|c|}
\hline Category & Source parts & Phytoconstituents & References \\
\hline \multirow[t]{9}{*}{ Alkaloids } & Leaves & $\begin{array}{l}\text { Donaxarine, gramine, donaxine, phenyl- } \beta \text {-naphthylamine, deoxyvasicinone, arundine, ardine, } \\
\text { donaxarine, donaxanine, donaxaridine, donine }\end{array}$ & $(8,63)$ \\
\hline & Rhizome & $\begin{array}{l}\text { Arundaline, arundalcohol, } \mathrm{N} \text {-acetyltryptamine, trans- } \mathrm{N}-(\mathrm{p} \text {-coumaroyl) serotonin, trans- } \mathrm{N} \text { - } \\
\text { feruloylserotonin, tuberosine } \mathrm{B}\end{array}$ & (10) \\
\hline & Rhizome & Donasine & (18) \\
\hline & Rhizome & $\begin{array}{l}\mathrm{N}, \mathrm{N} \text {-dimethyl-tryptamine, 5-methoxy- } \mathrm{N} \text { - methyltryptamine, bufotenine, dehydro-bufotenine, and } \\
\text { bufotenidine }\end{array}$ & (8) \\
\hline & $\begin{array}{l}\text { Roots and } \\
\text { rhizome }\end{array}$ & Arundaphine & (61) \\
\hline & $\begin{array}{l}\text { Epigeal and } \\
\text { roots }\end{array}$ & Arundinine & $(62)$ \\
\hline & Roots & $\begin{array}{l}\text { Arundamine, arundaline, arundanine, arundacine, arundarine, arundavine, arundafine, } \\
\mathrm{N} \text {-methyltetrahydro- } \beta \text {-carboline }\end{array}$ & $(63,64)$ \\
\hline & Leaves & Donaxine & (63) \\
\hline & Flowers & Gramine, N,N-dimethyltryptamine, bufotenine, 5-methoxy-N-methyl-tryptamine, eleagnine & $(66)$ \\
\hline \multirow[t]{2}{*}{$\begin{array}{l}\text { Sterols and } \\
\text { triterpenes }\end{array}$} & Leaves & $\begin{array}{l}\text { Campesterol, stigmasterol, stigmastanol, } \beta \text {-sitosterol, } \beta \text {-amyrin acetate, dihydrobrassicasterol, } \\
\text { stigmasta-3,5-dien-7-one, stigmast-4-en-3-one, stigmasta-3,6-dione, Friedelin, a-amyrenone; } \\
\beta \text {-amyrenone, cycloartenone }\end{array}$ & (65) \\
\hline & Rhizome & Squalene & (67) \\
\hline \multirow[t]{2}{*}{ Phenolics } & Rhizome & Xanthone, Xanthene & (67) \\
\hline & & $\begin{array}{l}\text { Guaiacol, o-Cresol, m-Cresol, methyl-guaiacol, 4-methylguaiacol, 4-methylcatechol, 4-ethylguaiacol, } \\
\text { 4-vinylguaiacol, 4-ethylcatechol, eugenol, 4-methylsyringol, E-isoeugenol, 4-ethylsyringol, } \\
\text { Z-isoeugenol, 4-vinylsyringol, E-propenylsyringol, Z-syringylpropanol }\end{array}$ & (71) \\
\hline Lignins & $\begin{array}{l}\text { Stem and } \\
\text { leaves }\end{array}$ & Guaiacyl, syringyl propane, p-hydroxyphenylpropane & (70) \\
\hline Carotenoids & & $\beta$-caroten, xanthophyll & $(72)$ \\
\hline
\end{tabular}




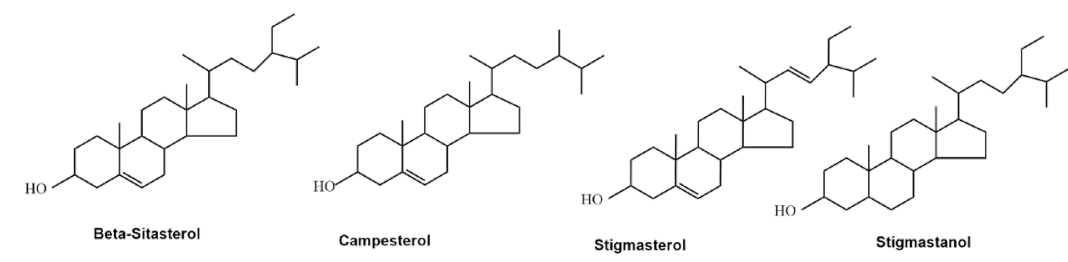

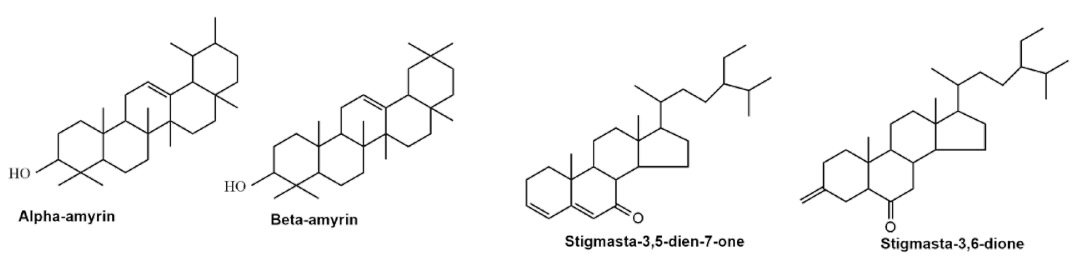

Figure 4. Chemical structure of some phytosterols isolated from Giant reed.<smiles>CC(=O)NCCCc1cc2ccccc2n1-c1cccc2c(CCN(C)C)cccc12</smiles><smiles>CNCC[C@H]1C(=O)N(c2cccc3c2C(CC=CN(C)C)CN3)c2ccccc21</smiles><smiles>CN(C)Cc1c[nH]c2ccccc12</smiles><smiles>CN(C)CCOc1ccc2c(c1)C(CC=NC(=O)N(C)C)CN2</smiles><smiles>CN(C)CCCc1cn(-c2c(O)ccc3c2c2ccccc2n3C)c2c1CCN(C)C2</smiles>

Figure 5. Chemical structure of some major alkaloids isolated from Giant reed.

terpenoids such as a-amyrenone, $\beta$-amyrenone, and cycloartenone (65) (Figure 6). Ghosal et al isolated several alkaloids such as gramine, N, N-dimethyltryptamine, bufotenine, 5-methoxy-N-methyltryptamine, and eleagnine from the flowers of A. donax L. (66).

From the gas chromatography-mass spectrometry (GC-MS) analysis of hexane, dichloromethane, ethyl acetate, and methanolic rhizomatous extracts, several phytoconstituents belonging to sterol groups, fatty acids, lipids, hydrocarbons, phenolics, terpenoids, xanthones, and xanthene were isolated (67). A study conducted by Coelho et al using the gas chromatography (GC) and GCMS analysis identified a series of long-chain n-fatty acids, n-alkanes, n-aldehydes, n-alcohols, monoglycerides, free and esterified sterols, triterpenols, steryl glucosides, steroid hydrocarbons, as well as steroid and triterpenoid ketones (68). Shatalov and Pereira reported that the Giant reed stem (including both nodes and internodes) on a percent dry weight basis contained 21.12\% lignin, 31.06\% cellulose, and 30.26\% hemicellulose (69). Giant reed lignin also constitutes a significant fraction (approximately (20\%-25\% by wt.) mainly composed of p-hydroxyphenyl $(\mathrm{H})$, guaiacyl $(\mathrm{G})$, and syringyl (S) phenylpropanoid units with a predominance of $\beta$-O-4 aryl ether linkages $(\sim 71 \%-82 \%)$, with the remaining part constituted by $\beta-\beta$, $\beta-5, \beta-1$, and $\alpha, \beta$-diaryl ether linkages $(70,71)$. However, the isolation and purification of lignin is a complicated process from any Poaceous plant owing to their strong association with cell wall carbohydrate polymers (71).

A recent phytochemical investigation, through acid 

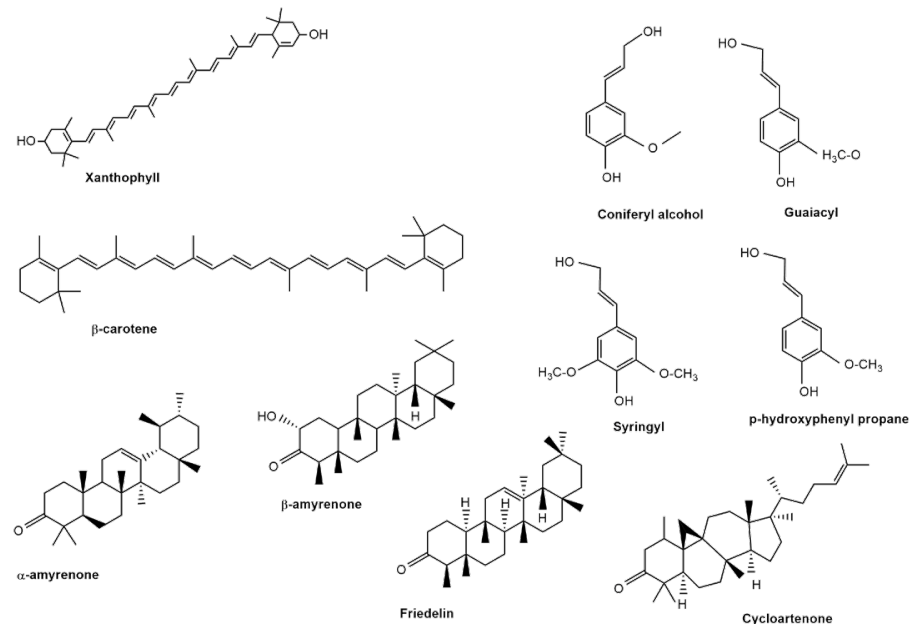

Figure 6. Chemical structure of some carotenoids, lignin, and terpenoids isolated from Giant reed.

catalysed hydrothermal conversion of lignocellulosic biomass to levulinic acid using advanced techniques like pyrolysis/gas chromatography/mass spectrometry (Py-GC/MS), thermogravimetric analysis/infrared spectroscopy (TGA/FTIR) and evolved gas analysis coupled with mass spectrometry (EGA-MS) revealed several lignin phenolic derivatives, such as guaiacol, o-cresol, m-cresol, methyl-guaiacol, 4-methylguaiacol, 4-methylcatechol, 4-ethylguaiacol, 4-vinylguaiacol, 4-ethylcatechol, eugenol, 4-methylsyringol, E-isoeugenol, 4-ethylsyringol, Z-isoeugenol, 4-vinylsyringol, E-propenylsyringol, Z-coniferyl alcohol, and syringylpropanol (71) (Figure 7). In a recent study, Sağir et al reported the concentration of soluble phenolics of $301 \pm 0.14 \mathrm{mg} / \mathrm{g}$ fresh weight (FW) in both stem and leaves of Giant reed (72).

\section{Pharmacological aspects}

Anti-bacterial activity

Few studies have claimed scientific evidence for the antibacterial activity of Giant reed. Shirkani et al evaluated the anti-bacterial activity of aqueous and methanolic extract of stem node of Giant reed against bacterial strains;
Staphylococcus aureus, Micrococcus luteus, Klebsiella, Escherichia coli, and Pseudomonas aeruginosa. The aqueous extract of the stem node exhibited anti-bacterial activity against methicillin-resistant Staphylococcus aureus at a concentration of $128 \mu \mathrm{g} / \mathrm{mL}$ (73). Moreover, in another study Sharma et al demonstrated that the methanolic root extract showed high efficacy against bacterial strains; $P$. aeruginosa with inhibition zone diameter (15.0 \pm 2.8) followed by Klebsiella pneumoniae (14.0 \pm 2.08$)$ and Streptococcus aureus $(14.0 \pm 6.0)$ at an inhibitory concentration of $40.0 \mu \mathrm{g} / \mathrm{mL}$. While in methanolic leaf extract, high efficacy was observed against Streptococcus aureus only, with maximum inhibition zone $(7.3 \pm 3.7)$ at the same concentration. However, a low activity was observed against $K$. pneumoniae $(6.6 \pm 3.5)$ at the same concentration (74).

In another study, Pansuksan et al observed that the dichloromethane (DCM) rhizome extract exhibited strong anti-bacterial activity against Bacillus subtilis and Bacillus cereus with inhibition zone $18.0 \mathrm{~mm}$ and $17.8 \mathrm{~mm}$, respectively. However, hexane, ethyl acetate, and methanolic extract showed lower efficacy against $B$.<smiles>COc1ccccc1O</smiles>

Guaiacol<smiles>Cc1ccccc1O</smiles>

o-cresol<smiles>CCc1ccc(O)c(O)c1</smiles>

4-ethyl catechol<smiles>Cc1cccc(O)c1O</smiles>

4-methyl catechol<smiles>C=CCc1ccc(O)c(OC)c1</smiles>

Eugenol<smiles>COc1cc(C)cc(OC)c1O</smiles>

4-methyl syringol<smiles>C=Cc1cc(OC)c(O)c(OC)c1</smiles><smiles>C=Cc1ccc(O)c(OC)c1</smiles>

Figure 7. Chemical structure of some lignin pyrolysed phenolics isolated from Giant reed. 
subtilis. No prohibitory effect was found against E. coli, S. aureus, and Candida albicans (67). The specific bioactive compounds responsible for anti-bacterial activities of Giant reed are not discussed in most of the studies. Therefore, future studies must focus on identifying the bioactive molecules and their mode of action. Furthermore, to elicit the anti-bacterial activities of Giant reed, more pathogenic strains are needed to be tested using different extraction solvents.

\section{Anti-oxidant activity}

In recent times much attention has been paid to natural anti-oxidants and their therapeutic potential for the cure of many complex disorders. The human body, due to metabolic and biochemical processes, produce several metabolic by-products called free radicals, which can damage cells, tissues, DNA, and promote aging. Antioxidants act as reducing agents that can quench the free radicals by donating hydrogen atoms and slow down the oxidation process, therefore protect cells and tissues from their deteriorating effects (4). A phytochemical investigation conducted by Sağir et al using leaf extract of the Giant reed reported a total anti-oxidant capacity of 3.4 $\pm 0.58 \mathrm{mg} / \mathrm{g}$ FW and total superoxide dismutase activity of $234.0 \pm 74$ units/g FW (72). The Giant reed is a rich source of secondary metabolites and derivatives of total phenols, non-tannic phenols, flavonoids, and tannins, which impart anti-oxidant properties (75). In another study, free radical scavenging activity of five percent aqueous extract of roots of Giant reed was investigated using 2,2-diphenyl2-picrylhydrazyl (DPPH) and Phosphomolybdenum complex. The DPPH free radical scavenging activity was $399.10 \mu \mathrm{g} / \mathrm{mL}$ and 0.98 for phosphomolybdenum complex (76). Phenolic compounds contribute significantly to anti-oxidant activity, and it is well evidenced in Piluzza and Bullitta (75), where they found the total anti-oxidant activity of acetone leaf extract ranged $6.64 \pm 0.13$ and $7.03 \pm 0.59 \mathrm{mmol} / 100 \mathrm{~g} / \mathrm{DW}$ against DPPH and ABTS free radical ions. All of the above-cited anti-oxidant studies have been conducted using total anti-oxidant capacity, $\mathrm{DPPH}$, and ABTS free radical scavenging assays in vitro conditions, which may or may not produce similar results in vivo conditions. Therefore, animal systems must be taken into consideration for free radical scavenging assays for the reliability of results.

\footnotetext{
Anti-algal and anti-fungal properties

Bloom forming algae (algal blooms) may pose a severe threat to water bodies, and underlying aquatic life primarily promotes fish mortality due to depletion of dissolved oxygen in the water and releasing harmful toxins (28). Therefore, the use of allelochemicals from aquatic plants to control algal blooms is a hot topic of research. A study conducted by Hong et al reported that methanolic shoot extract of Giant reed inhibited the growth of bloom-
}

forming cyanobacterium Microcystis aeruginosa (77). They fractioned the methanolic extract into acidic and neutral fractions, of which the neutral fraction had higher inhibitory growth than the acidic fraction. They accredited it to the presence of allelochemical gramine and proved to be one of the most effective anti-algal compounds known in aquatic plants.

Other allelochemicals isolated from methanolic shoot extract of Giant reed were 3-methyl-indole (Skatone), 2,4,6-trimethyl-benzonitrile, and 6,10, 14-trimethyl-2-pentadecanone (also called Phytone), 3,7,11,15-tetramethyl-2-hexadecan-1-ol (phytol), and 4,8,12,16-tetramethyl heptadecan-4-olide, which speculated to possess anti-algal properties (78). Pyrolytic vinegar or bio-oil from Giant reed is shown to have algicidal properties and inhibit red tide dinoflagellate Karenia brevis, which may cause neurotoxic poisoning to the marine organisms. The pyrolytic vinegar was predominantly composed of acetic acid, phenol, aldehyde, ketones, and ester, which could render antialgal properties (28). In another study, it was found that a neutral fraction of methanolic extract of Giant reed was able to suppress the growth of harmful golden alga Prymnesium parvum and the maximum algicidal activity was observed at $50 \mathrm{mg} / \mathrm{L}$ (79). Likewise in the case of Microcystis aeruginosa, gramine was proved to be the most potent growth suppressing compound in golden alga as well. Another indole compound skatole was also found to suppress the growth of golden alga; however, its algicidal activity was less potent than gramine. Since synthetic anti-algal compounds are toxic to aquatic life and suppress the growth of non-harmful algae as well, therefore, the algicidal activity of giant reed extract proved to be a promising tool for control of harmful algal blooms in water bodies. Gramine is also reported to suppress the growth of freshwater algae Desmodesmus armatus (80) and marine Chattonella marina (81). Information about the antifungal activity of Arundo donax L. is very sparse in the literature. However, its efficacy has been reported against few basidiomycetes i.e., Trametes versicolor, Coniophora puteana, Gloeophyllum trabeum, and Postia placenta (22). Anti-parasitic and anthelmintic uses

Badar et al studied the anti-parasitic and anthelmintic potential of Giant reed leaves. Crude aqueous methanolic extract of leaves was used to study in vitro (adult motility assay and egg hatch test) and in vivo (faecal egg count reduction test) anthelmintic activity against Haemonchus contortus. In adult motility assay, 56.7\% mortality of $H$. contortus was observed by 10 hours post-exposure with the extract at $50 \mathrm{mg} / \mathrm{mL}$. In egg hatch test, $A$. donax L. exhibited ovicidal activity with $\mathrm{LC}_{50}=200.1 \mu \mathrm{g} / \mathrm{mL}$; whereas, crude powder of $A$. donax resulted in $50.5 \%$ reduction in egg per gram of faeces in sheep, naturally infected with gastrointestinal nematodes (36). Anthelmintic activity of giant reed was also observed against cattle worms, such as 
Ascaris sp., Oesophagostomum sp., and Paramphistomum sp. $(82,83)$. In Sardinia, Italy, the leaves of Giant reed are used to cure coughs and intestinal worms in horses $(33,75)$.

\section{Anti-cancerous properties}

People in Calabria, Southern Italy, use a mixture of Arundo donax L. with Spartium junceum L. and Cynodon dactylon L. (Pers.) to treat tumors (the type of tumor is not specified) (84). Roots and leaves of Giant reed are used to treat cancer by local people in Bahawalpur, Pakistan (17). Root and stem powder with honey is given to cure cancer in Muzaffarabad, Pakistan (55). All the reports of anti-cancerous uses of this plant are restricted to the ethnic and local level. There is no scientific validation of the anti-cancerous properties of this plant so far. Although in 2005, a specific lectin named N-acetyl-Dglucosamine isolated from the rhizome of Giant reed was found to possess anti-proliferative properties towards human cancer cell lines and mitogenic towards human peripheral blood mononuclear cells (19). Of the several human cancer cell lines studied, the lectin at the highest concentration of $50 \mu \mathrm{g} / \mathrm{mL}$ showed the maximum effect of $62 \%$ against ovarian cell line (OVCAR-5) followed by SKN-N-MC (CNS), Hep-2 (Liver), SW-620 (Colon), and SK-N-SH (CNS) cell lines, with 59\%, 53\%, 51\% and 45\% growth inhibition, respectively.

Further studies are required to unravel the molecular mechanisms for the anti-proliferative properties of this plant. Therefore, traditional formulations and medicinal plants used for the ethnic cure of diseases must be screened pharmaceutically to pass ethnic knowledge to the modern system of medicine for the betterment of humankind.

Effect on skeletal and smooth muscle

Defatted ethanolic extract from rhizome of Giant reed is proved to hypotensive and antispasmodic against histamine, serotonin, and acetylcholine-induced spasms. Several pharmacological aspects of rhizomatous alkaloid bufotenidine have been studied on smooth muscles such as the intestinal loop of guinea pig, dog's intestine, the uterus of albino rats and guinea pigs, and dog's tracheal chain (8). A muscular spasm was observed after injection of alkaloid, and repeated doses followed tachyphylaxis in dog's intestine. In the isolated loop of the intestine, the alkaloid initially relaxes the muscle but when administered in doses above $20 \mathrm{mg} / \mathrm{kg}$ it alters the spasmodic effects of histamine, acetylcholine.

A muscular spasm was observed in isolated guinea pig uterus and rat uterus at an initial concentration of alkaloid $(20 \mu \mathrm{g} / \mathrm{mL}$ and $10 \mu \mathrm{g} / \mathrm{mL}$, respectively). However, at higher doses, the drug blocked acetylcholine-induced spasm. This might be the reason behind the stimulatory action of rhizome extract against menstrual discharge in traditional formulations (8). In contrast, there was no effect of alkaloid's higher doses on dog's tracheal chain, nor it influenced the acetylcholine-induced spasm. Surprisingly, there was no such kind of study conducted on human beings yet.

\section{Toxicological aspects}

The first toxicological report about Giant reed was published in 1969, where a rhizomatous extract was reported to be toxic towards albino mice and rats (8). The chief alkaloid responsible for toxicity was bufotenidine. When the alkaloid was administered to albino mice and rats at a dose of $10 \mathrm{mg} / \mathrm{kg}$, the sudden death of all five mice and ataxia in all ten rats was observed. Besides, the alkaloid produced head drop followed by death in rabbits in $5-6 \mathrm{mg} / \mathrm{kg}$ dose given against $0.3-0.5 \mathrm{mg} / \mathrm{kg}$ dose of alkaloid d-tubocurarine. The alkaloid bufotenidine acts as a neuromuscular blocking agent, which is mainly a toad poison. However, no toxicological aspects of Giant reed have been studied concerning human beings so far.

\section{Other uses}

Ethanolic rhizome extract from Giant reed has antipyretic properties due to the prevalence of bis-tryptamine alkaloid donasine (18). A significant reduction in the rat anal temperature was observed in donasine infused rats. Bioactive compounds in Giant reed are reported to show antifeedant activity against cotton boll weevil (Anthonomus grand). The strong inhibitory effect against cotton boll weevil is due to the presence of alkaloid N-(4'bromophenyl) 2,2-diphenylacetanilide in A. donax L. (85).

The Giant reed is a rich source of indole bases (gramine, N, N dimethyltryptamine, 5-methoxy-Nmethyltryptamine, 5-methoxy-N,N-dimethyltryptamine, bufotenine, bufotenidine, dehydrobufotenine, $\mathrm{Nb}$ Methyltetrahydroharman) and tetrahydro-p-carbolines. These alkaloids at low concentrations produce fine tremors, salivation, and hypermotility in mice and rats. However, a higher dose of alkaloids resulted in jumping movements, rapid tapping of the forelimbs, and paralysis of hindlimbs, convulsions, and respiratory arrest and completely antagonised the pre-treatment effect of the drug chlorpromazine (20). Therefore, the psychedelic effects of indole compounds and other phytoconstituents from giant reed should be screened at broad-spectrum while considering humans as well.

\section{Conclusion}

The present study summarised information about ethnomedicinal values, isolated chief phytoconstituents, and pharmacological aspects such as anti-bacterial, antioxidant, anti-proliferative, anthelmintic, and toxicological properties. Although all components of the plant are used to cure health ailments, chiefly rhizomes and roots find their mention across all formulations. In traditional healthcare practices, the plant has been extensively used 
in the treatment of skin disorders, urinary diseases, menstrual problems, diarrhoea, respiratory problems, and complex diseases such as cancer. However, the mode of consumption and administration is not mentioned in several studies. The scientific plausibility of cured ailments is also lacking. Yet, the plant has invaded several parts of Africa, America, and Mexico and has acquired the status of the worst invasive weed. Nonetheless, in European countries and the Indian subcontinent, the plant has been used in rural areas as a source of livelihood, medicines, substitute of firewood for locals. Therefore, further cultivation of Giant reed is recommended to generate income and livelihood resources for the local communities. Future ethnobotanical studies must focus on validating the reliability of formulations and modes of administration. Apart from this, the plant must be screened pharmaceutically for the isolation of bioactive molecules and the development of drug discovery and therapeutic potential.

\section{Acknowledgment}

Authors are thankful to the Chairperson Department of Botany, Panjab University; Chandigarh for providing all necessary research facilities.

\section{Authors' contribution}

All authors have equally contributed to data acquisition, analysis, and interpretation. PK and ANS conceived the idea. PK chiefly designed the manuscript, prepared figures, arrange tables, and draw chemical structures. GK helped in drawing chemical structures. SS, AS and RK also helped in the preparation of the manuscript and gave critical suggestions. ANS supervised the whole process and approved the final version of the manuscript.

\section{Conflict of interests}

The authors declare no conflict of interests.

\section{Ethical considerations}

All ethical issues have been carefully observed by authors.

\section{Funding/Support}

PK would like to thank University Grants Commission (UGC), Government of India for providing financial assistance in form of a Junior Research Fellowship [UGC Ref. No.: 443/(CSIR-UGC NET DEC. 2017)].

\section{References}

1. Oakins AJ. An Assessment and Management Protocol for Arundo donax L. in the Salinas Valley Watershed [thesis]. Monterey Bay, USA: California State University; 2001. p. $1-48$.

2. Jagtap SD, Deokule SS, Bhosle SV. Some unique ethnomedicinal uses of plants used by the Korku tribe of Amravati district of Maharashtra, India. J Ethnopharmacol. 2006;107(3):463-9. doi: 10.1016/j.jep.2006.04.002.
3. Azaizeh H, Fulder S, Khalil K, Said O. Ethnobotanical knowledge of local Arab practitioners in the Middle Eastern region. Fitoterapia. 2003;74(1-2):98-108. doi: 10.1016/ s0367-326x(02)00285-x.

4. Kumar A, Patil M, Kumar P, Bhatti RC, Kaur R, Sharma NK, et al. Mallotus philippensis (Lam.) Müll. Arg.: a review on its pharmacology and phytochemistry. J Herbmed Pharmacol. 2021;10(1):31-50. doi: 10.34172/jhp.2021.03.

5. Thorat AK, Mishra DN. Medicinal plants for the treatment of Mūtrakṛcchra in the Bṛhattrayī and Mādhava Cikitsā treatises of Āyurveda. Int J Herb Med. 2016;4(4):1-8.

6. Dhiren K, Singh HB. Traditional knowledge, economic prospects and conservation issues on Giant Reed (Arundo donax L) in Manipur, Northeast India. Pleione. 2015;9(2):481-93.

7. Khare CP. Indian Medicinal Plants: An Illustrated Dictionary. Berlin, Heidelberg: Springer-Verlag; 2007. p. 302.

8. Ghosal S, Dutta SK, Sanyal AK, Bhattacharya SK. Arundo donax L. (Graminae). Phythochemical and pharmacological evaluation. J Med Chem. 1969;12(3):480-3. doi: 10.1021/ jm00303a032.

9. Kumari K, Saggoo MI. Cytomorphology of some medicinal grasses from Hangrang valley of district Kinnaur, Himachal Pradesh. Int J Pharm Sci. 2016;8(5):187-90.

10. Liu QR, Li J, Zhao XF, Xu B, Xiao XH, Ren J, et al. Alkaloids and phenylpropanoid from Rhizomes of Arundo donax L. Nat Prod Res. 2021;35(3):465-70. doi: 10.1080/14786419.2019.1638378.

11. Ningthoujam SS, Das Talukdar A, Potsangbam KS, Choudhury MD. Traditional uses of herbal vapour therapy in Manipur, North East India: an ethnobotanical survey. J Ethnopharmacol. 2013;147(1):136-47. doi: 10.1016/j. jep.2012.12.056.

12. Pieroni A, Quave C, Nebel S, Heinrich M. Ethnopharmacy of the ethnic Albanians (Arbëreshë) of northern Basilicata, Italy. Fitoterapia. 2002;73(3):217-41. doi: 10.1016/s0367326x (02)00063-1.

13. Pieroni A, Quave CL, Santoro RF. Folk pharmaceutical knowledge in the territory of the Dolomiti Lucane, inland southern Italy. J Ethnopharmacol. 2004;95(2-3):373-84. doi: $10.1016 /$ j.jep.2004.08.012.

14. Upadhyay D. Ethnobotanicaly useful plants of Katarniaghat Wildlife Sanctuary, Uttar Pradesh, India. Int J Appl Res. 2016;2(2):24-9.

15. Mir TA, Jan M, Dhyani S. A Comprehensive account of ethno-medicinal uses of monocot flora (reported from February-June) of Karwapani forest Doon valleyUttarakhand. Int J Multidiscip Sci. 2018;1(2):22-7.

16. Ahmed MJ, Akhtar T. Indigenous knowledge of the use of medicinal plants in Bheri, Muzaffarabad, Azad Kashmir, Pakistan. Eur J Integr Med. 2016;8(4):560-9. doi: 10.1016/j. eujim.2016.01.006.

17. Nisar MF, Jaleel F, Waseem M, Ismail S, Toor Y, Haider $\mathrm{SM}$, et al. Ethno-medicinal uses of plants from district Bahawalpur, Pakistan. Curr Res J Biol Sci. 2014;6:183-90. doi: $10.19026 /$ crjbs.6.5191.

18. Jia AL, Ding XQ, Chen DL, Chao ZZ, Liu ZY, Chao RB. A new indole alkaloid from Arundo donax L. J Asian Nat Prod Res. 2008;10(1-2):105-9. doi: 10.1080/10286020600882452.

19. Kaur A, Singh J, Kamboj SS, Sexana AK, Pandita RM, Shamnugavel $\mathrm{M}$. Isolation of an N-acetyl-D-glucosamine specific lectin from the rhizomes of Arundo donax with 
antiproliferative activity. Phytochemistry. 2005;66(16):193340. doi: 10.1016/j.phytochem.2005.06.026.

20. Ghosal S. Occurrence of psychodelic substances in some Indian medicinal plants. Planta Med. 1972;21(2):200-9. doi: 10.1055/s-0028-1099544.

21. Al-Snafi AE. Therapeutic properties of medicinal plants: a review of their antibacterial activity. Int J Pharmacol Toxicol. 2015;6(3):137-58.

22. Mirza N, Mahmood Q, Pervez A, Ahmad R, Farooq R, Shah MM, et al. Phytoremediation potential of Arundo donax in arsenic-contaminated synthetic wastewater. Bioresour Technol. 2010;101(15):5815-9. doi: 10.1016/j. biortech.2010.03.012.

23. Pilu R, Bucci A, Badone FC, Landoni M. Giant reed (Arundo donax L.): a weed plant or a promising energy crop? Afr J Biotechnol. 2012;11(38):9163-74. doi: 10.5897/ajb11.4182.

24. Polunin O, Huxley A. Flowers of the Mediterranean. 2nd ed. London: Chatto \& Windus; 1987. p. 161.

25. Rawat VS, Rawat YS, Shah S. Indigenous knowledge and sustainable development in the Tones Valley of Garhwal Himalaya. J Med Plants Res. 2010;4(19):2043-7. doi: 10.5897/jmpr10.191.

26. Kutum A, Sarmah R, Hazarika D. An ethnobotanical study of Mishing tribe living in fringe villages of Kaziranga National Park of Assam, India. Indian J Fund Appl Life Sci. 2011;1(4):45-61.

27. Kantheti P, Alapati P. Review on tribal medicinal practices of north-east India for mosquito Repellency. J Pharmacogn Phytochem. 2017;6(5):1256-9.

28. Zheng H, Sun C, Hou X, Wu M, Yao Y, Li F. Pyrolysis of Arundo donax L. to produce pyrolytic vinegar and its effect on the growth of dinoflagellate Karenia brevis. Bioresour Technol. 2018;247:273-81. doi: 10.1016/j. biortech.2017.09.049.

29. Singh SK, Singh RB, Sharma HM. Ethnobotanical studies in relation to certain traditional culture of Chothe tribe in Bishnupur district of Manipur, India. Pleione. 2015;9(1):144-59.

30. Perdue RE. Arundo donax-source of musical reeds and industrial cellulose. Econ Bot. 1958;12(4):368-404. doi: 10.1007/bf02860024.

31. Bonanno G. Arundo donax as a potential biomonitor of trace element contamination in water and sediment. Ecotoxicol Environ Saf. 2012;80:20-7. doi: 10.1016/j. ecoenv.2012.02.005.

32. Ballero M, Poli F, Sacchetti G, Loi MC. Ethnobotanical research in the territory of Fluminimaggiore (southwestern Sardinia). Fitoterapia. 2001;72(7):788-801. doi: 10.1016/s0367-326x(01)00334-3.

33. Bullitta S, Piluzza G, Viegi L. Plant resources used for traditional ethnoveterinary phytotherapy in Sardinia (Italy). Genet Resour Crop Evol. 2007;54(7):1447-64. doi: 10.1007/s10722-006-9130-4.

34. Palmese MT, Uncini Manganelli RE, Tomei PE. An ethnopharmacobotanical survey in the Sarrabus district (southeast Sardinia). Fitoterapia. 2001;72(6):619-43. doi: 10.1016/ s0367-326x (01)00288-x.

35. Badar N. Documentation of indigenous antiparasitic practices and scientific evaluation of some ethnobotanicals for their anthelmintic activity [dissertation]. Faisalabad, Pakistan: University of Agriculture; 2011.

36. Singh B, Kaur H. In silico documentation of medicinal plants in Lacchiwala range, Dehradun forest division,
Uttarakhand (India). J Phytopharmacol. 2018;7(1):92-102.

37. Passalacqua NG, Guarrera PM, De Fine G. Contribution to the knowledge of the folk plant medicine in Calabria region (Southern Italy). Fitoterapia. 2007;78(1):52-68. doi: 10.1016/j.fitote.2006.07.005

38. Egamberdieva D, Mamedov N, Ovidi E, Tiezzi A, Craker L. Phytochemical and pharmacological properties of medicinal plants from Uzbekistan: a review. Journal of Medicinally Active Plants. 2017;5(2):59-75.

39. Al-Snafi AE. Traditional uses of Iraqi medicinal plants. IOSR J Pharm. 2018;8(8):32-96.

40. Basumatary N, Teron R, Saikia M. Ethnomedicinal practices of the Bodo-Kachari tribe of Karbi Anglong district of Assam. Int J Life Sci Biotechnol Pharma Res. 2014;3(1):161-7.

41. Kom LE, Tilotama K, Singh TD, Rawat AK, Thokchom DS. Ethno-medicinal plants used by the Kom community of Thayong village, Manipur. J Ayurvedic Herb Med. 2018;4(4):171-9.

42. Ikram S, Bhatti KH, Parvaiz M. Ethnobotanical studies of aquatic plants of district Sialkot, Punjab (Pakistan). J Med Plants. 2014;2(1):58-63.

43. Sekhar J, Pratap GP, Sudarsanam G, Prasad GP. Data on herbal remedies from the tribes of Chittoor district, Andhra Pradesh in India. Life Sci Leafl. 2011;17:621-30.

44. Srivastava TN, Rajasekharan S, Badola DP, Shah DC. An index of the available medicinal plants, used in Indian system of medicine from Jammu and Kashmir state. Anc Sci Life. 1986;6(1):49-63.

45. Vanila D, Ghanthikumar S, Manickam VS. Ethnomedicinal uses of plants in the plains area of the Tirunelveli-district, Tamilnanu, India. Ethnobot Leafl. 2008;12:1198-1205.

46. Sahal A, Hoque A, Mallick SK, Panda S. Medicinal uses of grasses by the tribal people in West Bengal: an overview. Int J Basic App Sci. 2014;3:63-70.

47. Jain A, Roshnibala S, Kanjilal PB, Singh RS, Singh HB. Aquatic/semi-aquatic plants used in herbal remedies in the wetlands of Manipur, Northeastern India. Indian J Tradit Know. 2007;6(2):346-51

48. Kamatchi A, Parvathi AS. Ethnomedico and ethnoeconomic studies of grasses utilization by Paliyar's tribal in Sadhuragiri hills, a part of Western Ghats, Tamil Nadu, India. World J Pharm Pharm Sci. 2017;6(8):2478-91. doi: 10.20959/ wjpps20178-9919.

49. Bandaranayake WM. Bioactivities, bioactive compounds and chemical constituents of mangrove plants. Wetl Ecol Manag. 2002;10(6):421-52. doi: 10.1023/a:1021397624349.

50. Hussain K, Nisar MF, Majeed A, Nawaz K, Bhatti KH. Ethnomedicinal survey for important plants of Jalalpur Jattan, district Gujrat, Punjab, Pakistan. Ethnobot Leafl. 2010;2010(7):11.

51. Bharadwaj J, Seth MK. Medicinal plant resources of Bilaspur, Hamirpur and Una districts of Himachal Pradesh: an ethnobotanical enumeration. J. Med. Plants Stud. 2017;5(5):99-110.

52. Raj AJ, Biswakarma S, Pala NA, Shukla G, Vineeta, Kumar $\mathrm{M}$, et al. Indigenous uses of ethnomedicinal plants among forest-dependent communities of Northern Bengal, India. J Ethnobiol Ethnomed. 2018;14(1):8. doi: 10.1186/s13002018-0208-9.

53. Dall'Acqua S, Cervellati R, Loi MC, Innocenti G. Evaluation of in vitro antioxidant properties of some traditional Sardinian medicinal plants: investigation of the high 
antioxidant capacity of Rubus ulmifolius. Food Chem. 2008;106(2):745-9. doi: 10.1016/j.foodchem.2007.06.055.

54. Khan M, Yadava PS. Herbal remedies of asthma in Thoubal district of Manipur in North East India. Indian J Nat Prod Resour. 2010;1(1):180-4.

55. Ahmed MJ, Akhtar T. Indigenous knowledge of the use of medicinal plants in Bheri, Muzaffarabad, Azad Kashmir, Pakistan. Eur J Integr Med. 2016;8(4):560-9. doi: 10.1016/j. eujim.2016.01.006.

56. Güneş S, Savran A, Paksoy MY, Koşar M, Çakılcıoğlu U. Ethnopharmacological survey of medicinal plants in Karaisalı and its surrounding (Adana-Turkey). J Herb Med. 2017;8:68-75.

57. Sarmah R. Commonly used non-timber forest products (NTFPs) by the Lisu tribe in Changlang district of Arunachal Pradesh, India. J Front Res. 2010;5:68-77.

58. Kumar R, Bhagat N. Ethnomedicinal plants of district Kathua (J\&K). Int J Med Aromat Plants. 2012;2(4):603-11.

59. Bhatia H, Sharma YP, Manhas RK, Kumar K. Ethnomedicinal plants used by the villagers of district Udhampur, J\&K, India. J Ethnopharmacol. 2014;151(2):1005-18. doi: 10.1016/j.jep.2013.12.017.

60. Buragohain J. Folk medicinal plants used in gynecological disorders in Tinsukia district, Assam, India. Fitoterapia. 2008;79(5):388-92. doi: 10.1016/j.fitote.2008.03.004.

61. Khuzhaev VU, Zhalolov I, Turgunov KK, Tashkhodzhaev B, Levkovich MG, Aripova SF, et al. Alkaloids from Arundo donax. XVII. structure of the dimeric indole alkaloid arundaphine. Chem Nat Compd. 2004;40(3):269-72. doi: 10.1023/B:CONC.0000039139.30391.2c.

62. Zhalolov I, Khuzhaev VU, Tashkhodzhaev B, Levkovich MG, Aripova SF, Abdullaev ND. Alkaloids of Arundo donax VII. A spectroscopic and X-ray structural investigation of arundinine-a new dimeric alkaloid from the epigeal part of Arundo donax. Chem Nat Compd. 1998;34(6):706-10. doi: $10.1007 / \mathrm{bf} 02336098$.

63. Khuzhaev VU. Alkaloids of the flora of Uzbekistan, Arundo donax. Chem Nat Compd. 2004;40(2):160-2. doi: 10.1023/B:CONC.0000033935.05529.e8.

64. Khuzhaev VU, Zhalolov IZ, Levkovich MG, Aripova SF, Shashkov AS. Alkaloids of Arundo donax L. Russ Chem Bull. 2004;53(8):1765-7. doi: 10.1007/s11172-005-0033-x.

65. Chaudhuri RK, Ghosal S. Triterpenes and sterols of the leaves of Arundo donax. Phytochemistry. 1970;9:1895-6.

66. Ghosal S, Chaudhuri RK, Dutta SK. Alkaloids of the flowers of Arundo donax. Phytochemistry. 1971;10:2852-3.

67. Pansuksan K, Sukprasert S, Karaket N. Phytochemical compounds in Arundo donax L. rhizome and antimicrobial activities. Pharmacogn J. 2020;12(2):287-92. doi: 10.5530/ pj.2020.12.45.

68. Coelho D, Marques G, Gutiérrez A, Silvestre AJD, del Río JC. Chemical characterization of the lipophilic fraction of giant reed (Arundo donax) fibres used for pulp and paper manufacturing. Ind Crops Prod. 2007;26(2):229-36. doi: 10.1016/j.indcrop.2007.04.001.

69. Shatalov AA, Pereira H. Arundo donax L. reed: new perspectives for pulping and bleaching. Part 4. Peroxide bleaching of organosolv pulps. Bioresour Technol. 2005;96(8):865-72. doi: 10.1016/j.biortech.2004.09.005.

70. You TT, Mao JZ, Yuan TQ, Wen JL, Xu F. Structural elucidation of the lignins from stems and foliage of Arundo donax Linn. J Agric Food Chem. 2013;61(22):5361-70. doi: $10.1021 / \mathrm{jf} 401277 \mathrm{v}$.

71. Licursi D, Antonetti C, Mattonai M, Pérez-Armada L, Rivas S, Ribechini E, et al. Multi-valorisation of giant reed (Arundo donax L.) to give levulinic acid and valuable phenolic antioxidants. Ind Crops Prod. 2018;112:6-17. doi: 10.1016/j.indcrop.2017.11.007.

72. Sağir C, Everest ZA, Keleş Y. The comparative investigation of the antioxidant activities of some species belonging to the Lamiaceae and Poaceae families. Ant J Bot. 2018;2(2):52-9. doi: 10.30616/ajb.397590.

73. Shirkani A, Mozaffari M, Zarei M. Antimicrobial effects of 14 Medicinal plant speices of Dashti in Bushehr province. Iran South Med J. 2014;17(1):49-57.

74. Sharma A, Singh S, Kumar P, Singh AN. Evaluation of antibacterial potential of an invasive grass (Arundo donax L.) in a lower Siwalik region, India. Plant Arch. 2020;20(2):35804.

75. Piluzza G, Bullitta S. Correlations between phenolic content and antioxidant properties in twenty-four plant species of traditional ethnoveterinary use in the Mediterranean area. Pharm Biol. 2011;49(3):240-7. doi: $10.3109 / 13880209.2010 .501083$.

76. Menezes PR, Schwarz EA, Santos CAM. In vitro antioxidant activity of species collected in Paraná. Fitoterapia. 2004;75(3):398-400. doi: 10.1016/j.fitote.2004.01.014.

77. Hong Y, Hu HY, Sakoda A, Sagehashi M. Straw preservation effects of Arundo donax L. on its allelopathic activity to toxic and bloom-forming Microcystis aeruginosa. Water Sci Technol. 2011;63(8):1566-73. doi: 10.2166/wst.2011.209.

78. Hong Y, Hu HY, Sakoda A, Sagehashi M. Isolation and characterization of antialgal allelochemicals from Arundo donax L. Allelopathy J. 2010;25(2):357-68.

79. Patiño R, Rashel RH, Rubio A, Longing S. Growthsuppressing and algicidal properties of an extract from Arundo donax, an invasive riparian plant, against Prymnesium parvum, an invasive harmful alga. Harmful Algae. 2018;71:1-9. doi: 10.1016/j.hal.2017.11.005.

80. Laue P, Bährs H, Chakrabarti S, Steinberg CE. Natural xenobiotics to prevent cyanobacterial and algal growth in freshwater: contrasting efficacy of tannic acid, gallic acid, and gramine. Chemosphere. 2014;104:212-20. doi: 10.1016/j.chemosphere.2013.11.029.

81. Liu F, He ZB, Li HY, Liu JS, Yang WD. Inhibition of five natural products from Chinese herbs on the growth of Chattonella marina. Environ Sci Pollut Res Int. 2016;23(17):17793-800. doi: 10.1007/s11356-016-6755-5.

82. Sharatkumar S, Dhanachand C, Mohilal N. Study on the efficacy of certain medicinal plants on gastrointestinal helminths of cattle. Indian Vet J. 2004;81(5):497-8.

83. Al-Snafi AE. Antiparasitic effects of medicinal plants (part 1)-a review. IOSR J Pharm. 2016;6(10):51-66.

84. Leporatti ML, Impieri M. Ethnobotanical notes about some uses of medicinal plants in Alto Tirreno Cosentino area (Calabria, Southern Italy). J Ethnobiol Ethnomed. 2007;3:34. doi: 10.1186/1746-4269-3-34.

85. Miles DH, Tunsuwan K, Chittawong V, Hedin PA, Kokpol $\mathrm{U}, \mathrm{Ni} \mathrm{CZ}$, et al. Agrochemical activity and isolation of N-(4'bromophenyl)-2,2-diphenylacetanilide from the Thai plant Arundo donax. J Nat Prod. 1993;56(9):1590-3. doi: 10.1021/ np50099a020. 